\title{
KIRKELIV I HADERSLEV OMKRING 1864
}

\author{
AF \\ VALDEMAR AMMUNDSEN \\ DR. THEOL., BISKOP OVER HADERSLEV STIFT, HADERSLEV
}

Før I85o var Ordningen i de nordslesvigske Købstæder jo den unaturlige, 1 at Skolesproget var tysk, og at Førstepræsten prædikede paa Tysk ved Højmessen, medens Andenpræsten prædikede paa Dansk til Aftensang eller Froprædiken. Saaledes ogsaa i Haderslev i Vor Frue Sogn, medens Gammel Haderslev regnedes for et Landsogn og derfor havde dansk Kirke- og Skolesprog. Det kunde da ske, at Førstepræsten kun ufuldkomment beherskede Dansk, hvad der blev særlig uheldigt, hvis han tillige var Provst og skulde have Tilsyn med Skolerne. Dette gjaldt f. Eks. Adolf Heinriah Strodtmann (i 753-i839), der fra 1797 var Provst og Førstepræst i Haderslev. Naar Fr. Nielsen siger: „Det danske Sprog mægtede han aldrig, saa gammel han blev, at tilegne sig, " maa det dog ikke forstaas, som om han slet ikke talte Dansk; han var en født Holstener, men gjorde sig Umage for at lære det danske Sprog; synderlig Færdighed deri naaede han dog næppe'. Men i de Dage gjorde Sproget jo intet som helst Skaar i Loyaliteten. Da Frederik VI som Kronprins besøgte Haderslev I802, hyldede Strodtmann ham med et begejstret tysk Digt, og da han som Konge I83i kom til den nye Skoles Indvielse, modtog han ham med tysk Tale.

Ved Udbruddet af Opstanden 1848 stillede jo næsten alle Præster i Slesvig Stift sig paa slesvig-holstensk Side; de havde ved Universitetet i Kiel tilegnet sig den der docerede Opfattelse af Hertugdømmernes Historie og statsretslige Forhold. De faa dansksindede Præster blev fordrevet.

Til Superintendent for den nordlige Del af Slesvig udnævnte den slesvigholstenske Regering Provst Rehнoff i Aabenraa. I Fjelstrup var U. S. Boesen, den senere Biskop ${ }^{2}$, blevet Præst I846; han blev 3. August I 848 afsat af den sles-

1 Fr. Nielsen i Brickas Biografiske Lexikon XVI, S. 486. I. S. Strodtmann: Der Consistorialrath A.H.S.s nach seinem Leben und Wirken. 185I. S. 81 ff.; III f; 121. 2 Jvfr. herom H. F. Petersen i Aarbøger 1928, S. I6 I ff. 
vigholstenske Regering, som i Stedet udnævnte Ghristian Petersen, der havde været Præst i Hellevad-Egvad, men en Tid havde været fængslet af de danske som mistænkt for Spioneri. Io. November I849 afsatte den i Frederik VII's Navn regerende Bestyrelseskommission (Danskeren Tillisch, Preusseren Eulenburg og Englænderen Hodges) ham og genindsatte Boesen i Embedet. Petersen gik sydpaa, r864 blev han Præst i Bov. Denne Sag skulde faa vidtrækkende Følger.

Hans Peter Prahl (1808-1869) var født i Vedsted, Sydvest for Haderslev, som Søn af en Bornholmer, der før havde været Præst i Sommersted, og som 1809I830 var Førstepræst og Provst i Tønder; fra herrnhutisk Side skildres han som „ingen Ven af det aandelige Liv" ${ }^{1}$; han hørte Oplysningstiden til, omend han var af de mere positive. Sønnen Hans Peter Prahl studerede i Kiel og blev I 840 Sognepræst i Østerløgum. Han blev ret kendt gennem sit vidtudbredte Udtog af Bibelhistorien I846, hvilende paa en i Calw i Württemberg udgivet Samling bibelske Historier, forsynet med tarvelige Illustrationer. Bogen er tilegnet „Deres Højærværdighed Herr Provst Rehhoff, Kirkeprovst i Apenrade Provsti og Sognepræst for Apenrade Menighed, Ridder af Dannebrogen, Skolevæsenets nidkjære Ven ".

To Aar efter stod baade Prahl og hans Provst i den slesvigholstenske Lejr. Rehhoff blev jo Leder af Nordslesvigs Kirkevæsen, og det er sikkert ham, som foranledigede, at Prahl af den slesvigholstenske Regering I 848 blev kaldet til Sognepræst for Øsby og Provst for Haderslev Provsti. Sammen med det store Flertal af Provstiets Præster underskrev han i Sommeren 1849 en Erklæring i slesvig-holstensk Aand. Han søgte forgæves at hindre Afsættelsen af Pastor Petersen i Fjelstrup. Da han vægrede sig ved at genindsætte den danske Degn i Hoptrup, blev han af Bestyrelseskommissionen afsat Io. Januar I850; 2 I. Januar fulgte Rehhoffs Afsættelse.

Prahl offentliggjorde en Protest mod sin Afsættelse, som han stemplede som en ren Voldshandling. Han gik til Tyskland og blev Præst i Wetzlar i Rhinprovinsen. En holstensk Præst, Th. Hansen i Lunden, der som Gymnasielærer i Wetzlar havde levet i nær Venskab med Prahl, skildrer ham som en alvorlig, ærlig, ved første Øjekast indesluttet Mand, samvittighedsfuld og nøjagtig, der omhyggelig udarbejdede sine Prædikener; i sin Iver for ikke at lade noget uklart kunde han undertiden gennem en udførlig Slutningspassus noget svække Indtrykket af det oprindelige og selvoplevede ${ }^{2}$.

I Prahls Sted blev Boesen konstitueret som Provst, senere definitivt udnævnt. Men 21. Januar 1850 sendte I7 Præster i Provstiet ham et Brev, hvori de prote-

1 I. Brodersen: Fra gamle Dage, 1912, S. 276. Om hans Iver for Folkeoplysning C. M. Jensen i Asylvennen Aug. 1930. ${ }^{2}$ Nekrologen over Prahl i Schleswigholsteinisches Kirchenund Schulblatt 1869 , Nr. 52. 
sterede mod Prahls Afsættelse og Boesens Konstitution; de indrømmede, at hans Navn tidligere havde haft en god Klang, men nu havde han virket med til at nedbryde Kirkens Rettigheder; han burde derfor nedlægge sit Hverv; de ønskede, at Herren vilde ydmyge ham til at gøre dette Skridt. Brevet blev offentliggjort. De kirkelige Myndigheder forlangte nu af de Præster, der havde underskrevet, at de i „Dannevirke“ skulde indrykke en Erklæring om, at de ikke tilsigtede at nægte Bestyrelseskommissionen eller den konstituerende Provst Boesen den skyldige Lydighed. Da de gennemgaaende vægrede sig herved, blev de afsat. Ofte var der kommen andre Stridspunkter til. Andenpræsten (Diaconus) ved Frue Kirke H. P. Schlaikier nægtede at fungere i Vakancen efter Prahl i Øsby; i hans Sted konstitueredes Fr. Helweg. Førstepræsten (Hauptpastor) JoHANN Sigismund Strodtmann (I 797-i888), Søn af den ovennæunte Provst, havde studeret i Kiel og Halle og været Lærer ved Petri Skole i København og ved Skolerne i Husum og Flensborg; I83o havde han udgivet en dansk Grammatik. Han fulgte $184^{\circ}$ efter sin Fader som Førstepræst, men blev ikke Provst. Han var en Hovedmand for de Erklæringer, Præsterne udsendte, og han nægtede at fungere sammen med Helweg, ligesaa at virke i den ny udnævnte Fattigkommission og Skolekommission. Efter sin Afsættelse fik han ikke, som de fleste afskedigede, Præsteembede i Tyskland, men levede i yderst knappe Kaar i Wandsbeck, beskæftiget med Privatundervisning og Studier paa forskellige Omraader, især klassisk Filologi; ogsaa Digte offentliggjorde han. I857 blev han Æresdoktor i Jena ${ }^{1}$. Hans Søn Adolf Heinrich Strodtmann (1829-1879) havde været frivillig i den slesvigholstenske Armé; efter et ret æventyrligt Liv, hvor Frihedstrangen havde drevet ham til Amerika, levede han i Tyskland som en meget alsidig Litterat, der bl. a. ogsaa skrev om det aandelige Liv i Danmark, men blev mest bekendt gennem sin Biografi af Heine.

Ogsaa Præsten ved Hospitalskirken H. P. Godt (ikke at forveksle med den senere Generalsuperintendent) blev afsat. Blandt de øvrige Præster i Provstiet, som fik Afsked, maa vi her nævne C. E. Muller (I81 2-I897, tog Afsked I89o), født i Haderslev; han havde været Kateket i Præstø og paa den Tid staaet i Forbindelse med Brødrene Fenger, P. C. Kierkegaard og Salmedigteren Olden-

1 Strodtmann har i Skriftet Satura (= Frugtskaal; Blanding) I. 1864 givet en Skildring af Prahls og sin egen Afsættelse, med Aftryk af adskillige af Sagens Dokumenter. Bogen indeholder tillige etymologiske Undersøgelser. Om Begivenhederne desuden I. H. Weiland: Die Geistlichkeit Schleswig-Holsteins während der Erhebung. Schriften des Vereins für Schleswigholsteinische Kirchengeschichte II Reihe. 3. Heft. 1898. Især S. 69 ff.; 90 f. P. Lauridsen: Mellem Slagene. Sønderjydske Aarbøger r goo. S. 74I; $97 \mathrm{ff}$. 
burg; han blev I845 Sognepræst i Hammelev. En dansk Præstekone, der var Søsterdatter af Müller og som ung kom $i$ hans Hus, har skildret mig ham som en from, alvorlig Præst, der ikke var meget politisk, men som nu, da han maatte vælge, dog gik til den slesvigholstenske Side. Efter Afsættelsen blev han snart Provst i Doberan i Mecklenburg.

Arbejdet i Haderslev Vor Frue Sogn begyndte nu under helt nye Forhold. De tre Præster var afskedigede, desuden Kirkens Personale undtagen Graveren og samtlige Lærere; alle havde de stillet sig imod de af Bestyrelseskommissionen trufne Anordninger. Ved Reskripterne af $185^{1}$ kom Dansk til sin Ret i Sognet. Baade den lærde Skole og Folkeskolerne blev danske; baade Højmessen og Aftensang skulde være skiftevis paa Dansk og Tysk og besørges efter Tur af begge Præster; man vilde undgaa, at de politiske Spaltninger paavirkede Menighedens Forhold til Præsterne. I Hospitalskirken - som ogsaa før i Gammel Haderslev - prædikedes der paa Dansk.

Det var tre mærkelig betydelige Mænd, som fik Præstegerningen overdraget ${ }^{2}$. Først kom Hans Friedrich Helweg (I8I6-i 89I). Han var født i Bordesholm i Holsten som Søn af en Distriktskirurg, der straks efter flyttede til Odense, hvor hans Broder Ludvig, den bekendte Kirkehistoriker, blev født I818. Fr. Helweg gik i Skole i Odense og Slesvig og blev I833 Student i Kiel; ogsaa i Erlangen studerede han. 1839 tog han den slesvigske theologiske Eksamen paa Gottorp. Han blev Huslærer i Sønder Højrup paa Fyen, hvor hans Bibellæsninger i høj Grad paaskønnedes af de vakte. Da Sognepræsten i Øster Starup og Vester Nebel ved Kolding Fr. Hammerich var syg, forvaltede han som Kapellan Embedet I 842-43. Birkedal, der da som Præst i Sønder Omme gjorde hans Bekendtskab, siger: „Han var en ualmindelig levende Personlighed . . . en Aandsprædikant ... Den Gang ( 0 : da han var paa Fyen) stod han endnu i stærk kristelig Gæring og var vist saare uklar; men mægtig henrevet var han selv paa Prædikestolen og henrev ved sin brusende Talestrøm. Man fortæller endnu der, hvorledes hans skønne Aasyn straalede under de bevingede Ord,

1 H. Hjelholt: Den danske Sprogordning og det danske Sprogstyre i Slesvig mellem Krigene (1850-1864). 1923, S. I8 f.; 2 I ff.; 94; 126 ff.; 134. 2 Til det følgende jfr.: Johannes Fibiger: Mit Liv og Levned som jeg selv har forstaaet det, udg. af hans Plejesøn Karl Gjellerup I 898. P. P. Jørgensen: H. P. Kofoed-Hansen med særligt Henblik paa Søren Kierkegaard. I92o. Denne 650 Sider store Bog er overordentlig righoldig; her er ogsaa benyttet mange ad privat Vej skaffede Oplysninger og de ved Udgivelsen ikke medtagne Dele af Fibigers Selvbiografi. J. Johansen: Oplevelser i Sønderjylland. 1899. Desuden Artikler om de omtalte Personer i Brickas Biografisk Lexikon. Om Helwegs Tiltrædelse Strodtmanns Satura, om hans Personlighed V. Birkedal: Personlige Oplevelser $i$ et langt Liv. II. I8go, S. $34 \mathrm{ff}$. 
medens hans lange Haar bølgede om hans Isse under hans stærke Hovedbevægelser . . . Hele store Skarer drog stadig, tit milevidt borte fra, for at høre ham prædike (i Starup), og han stod i den Tid som den Præst, de Opvakte helst vilde høre, og som de saa op til med Beundring; thi der var en Ild og henrivende Magt i hans Ord, der susede hen over Forsamlingen. " 1846 blev han Forstander for Rødding Højskole, I 848-49 fungerede han som Feltpræst. Saadan en Mand skulde synes vel skikket til Gerningen i Haderslev. Han var en dybt tænkende Mand og en stor Prædikant, lige fortrolig med tysk og dansk Sprog og Aandsliv, ja egentlig mest bundende i Tysk; Birkedal kom til at høre ham holde sin private Andagt; da læste han højt af Bibelen paa Tysk; og Johansen finder, at han talte smukkere Tysk end Dansk. Og dog blev hans Gerning for en stor Del en Skuffelse; især blev hans tyske Gudstjenester daarlig besøgt. Fra Begyndelsen blev han modtaget med de voldsomste Angreb i de tysksindede Aviser, som Nordslesvigsk Tidende. Man stemplede ham som en Renegat, der som Student i Kiel havde været ivrig tysk for saa at blive fanatisk dansk Agitator; særlig beskyldtes han for ved Krigens Begyndelse at have medvirket til Fængslingen af en Dr. med. Marcus. Unægtelig hørte han til det ivrigt nationale Parti; sammen med Rektor Thrige og Lembcke indmeldtes han i Efteraaret I850 i "Harmonien "1. Hertil kom hans Dunkelhed. Han tumlede altid med høje Spekulationer og Syner. Hans Læremestre var dels den dybsindige, men vanskeligt forstaaelige ErlangerProfessor Hofmann, der stræbte efter et Totalsyn paa Historien og fordybede sig i Profetien, dels Grundtvig. Hans vidtløftige Bøger, som han tildels skrev i Haderslev-Tiden (saaledes „Spaadommene eller Gud i Historien“ i 3 Bind I 855-62) er kun blevet lidet læst. Birkedal forklarer maaske noget af det tragiske $i$ hans Væsen ved at sige: han var egentlig tysk anlagt, men overbevist om Danmarks Ret har han villet være dansk; herved har hverken Tyskheden eller Danskheden faaet Lov til helt at udfolde sig efter sit ejendommelige Væsen. Man kan hertil føje, at han havde særlig ugunstige Betingelser for, at de to Kulturer i ham paa naturlig Maade kunde befrugte hinanden, ja gaa organisk sammen. Han var ikke opvokset i Grænselandet, hvor de paa historisk begrundet Maade mødes, men dels paa rent tysk, dels paa rent dansk Grund; og da han kom hertil, var det midt i en oprivende national Kamp, hvor der fra hver Side krævedes et Enten-Eller og kun var liden Sans for Forsoning.

Helweg blev I 850 Andenpræst og var udset til Førstepræst efter Strodtmann. Men da der var rejst en saa voldsom Agitation imod ham, foretrak han at undgaa en pinlig Valghandling og blev foreløbig i sin mere beskedne Stilling.

1 M. C. Matthiesen: Harmonien gennem 6o Aar. 1909, S. 16. 
Førstepræst blev da Hans Peter Kofoed-Hansen (1813-i893). Han var en Mand, der allerede kunde opvise et ikke ubetydeligt Forfatterskab af æsthetisk, religiøs-filosofisk og national Art, havde været Adjunkt i Odense og en kort Tid Præst paa Christianshavn. Han brændte efter at komme til at virke i Slesvig; helst vilde han have det Embede som dansk Præst i Flensborg, der blev besat med Graae. 1854, da Boesen udnævntes til Biskop, blev Kofoed-Hansen Provst. Men han trykkedes af de mange Forretninger, hvorfor han I855 med Glæde tog Embedet som Sognepræst for Gammel Haderslev; det mindre Sogn kunde han lettere forene med Provstegerningen; han foretrak ogsaa det rent danske Kirkesprog for den tvesprogede Menighed, omend han gennem Studier, Rejser og Lærergerning var fortrolig med tysk Sprog og Aandsliv. Helweg blev da Førstepræst ved Mariekirken. (Embedet som Andenpræst blev besat med G. W. Møller, der 1863 afløstes af C. H. Bruhn, som 1877 blev Sognepræst i Gram). Johannes Fibiger siger, at der blandt Præsterne kun var én Mening om, at Kofoed-Hansen var dem alle overlegen, en af dem, der uden at man ved hvorfor, altid kommer til at gaa i Spidsen. Han var en alvorlig Præst, ogsaa Formand for det Haderslevske Bibelselskab. Han var en noget tungsindig Mand; hvad han producerede var vægtigt og tog Tid; han var grundig studerende, en grublende Mystiker. Der var noget aristokratisk over ham; han passede godt til at være gift med en Komtesse Moltke. De levede i Omgang med Thriges, Lembckes, Fr. Helwegs, Fibigers og Apotheker Aggersborgs; den begavede Fru Pauline Aggersborg siger dog, at han ikke egnede sig til Selskabelighed, men uvilkaarlig lagde et Tryk over Stemningen. I det nationale og politiske Liv tog han ikke videre Del. Han havde stor Hengivenhed for Frederik VII og undslog sig end ikke, da det saa at sige paa Embedsvegne tilfaldt ham at tale for Grevinde Danner ved den Frokost, der efter Kongens Ønske blev holdt paa Rødding Højskole efter Indvielsen af Kirken i Jels I854. Oprindelig var han nationalliberal, men skiftede stærkt Anskuelse. Han blev Modstander af Demokratiet og mente, at den nationalliberale Politik voldte Danmarks Ulykke, ved "paa ti Aar at sætte Planer i Værk, hvis Udførelse krævede et halvt Aarhundrede“; Grundloven 1849, der ved Friheden gav Kongeriget helt andre Kaar end Slesvig, og dernæst Novemberforfatningen ${ }_{1} 863$ overskar $\mathrm{i}$ hans $\varnothing_{j n e}$ Baandet ved Kongeaaen. Hans Hustru var i Slægt med Carl Moltke, med hvem han kom i personlig Forbindelse; han blev ham nu Idealet af en Statsmand.

Præst ved Hospitalskirken og tillige Lærer ved Latinskolen blev JoHANNEs Fibiger (1821-1897), en fin, indadvendt, frisindet Præst, tillige Digter og optaget af religionshistoriske Studier, en nær Ven af Lembcke. 
Ejendommelig er den stærke Indflydelse fra Søren KierkegaArd i Haderslev i disse Aar. P. C. Косн (1807-1880), „Dannevirkes“ Udgiver, var en religiøst stærkt bevæget Mand, udgaaet fra den gamle sønderjydske Pietisme. Han fandt noget hermed beslægtet i Kierkegaards Forkyndelse af Inderlighed og Bod, omend han dadlede det „kolde og menneskefjendtlige“ i „Øjeblikket“. I „Dannevirke" skrev Politikeren P. G. Zahle (1825-1898) mange Artikler, hvori han udfra Kierkegaard og med Kochs Tilslutning hævdede, at Præster er en jødisk og hedensk Levning - langt senere blev han dog selv en paaskønnet Præst. Den tidligere Skræddersvend, nu Lærer Mogens Sommer (1829-igor) var I 853 blevet afskediget som Lærer i Rørvig paa Sjælland efter en Strid med Sognepræsten. Han var nu bleven Lærer ved Borgerskolen i Haderslev; han holdt Vækkelsesmøder i Skolen, hvor der deltog 2-300 Mennesker, mest af den jævnere Klasse, dog ogsaa nogle finere Damer. Det blev ogsaa her til voldsomme Angreb paa Præsterne; Sommer beskyldte Fr. Helweg for falsk Lære og tog derpaa sin Afsked og rejste rundt, mest i Jylland, og tordnede mod Folkekirken. Senere virkede han ogsaa i Amerika.

Der var i dette hele Røre meget sekterisk og usundt. Men der var ogsaa Mennesker, som virkelig fik Uro i Retning af Inderliggørelse. Et Brev fra Zahle fra 19. November 1855 er i min Besiddelse, hvori han fortæller nærmere Omstændigheder ved Kierkegaards Død. Det er rettet til John Aschlund (1826-1872), theologisk Kandidat og Adjunkt ved Haderslev lærde Skole, Forfatter af mange mindre Skrifter og Afhandlinger af æsthetisk, historisk og religiøs Art, ogsaa af Digte (f. Eks. „I Verden gives der Sorger nok “); Zahles Brev viser, at Aschlund ogsaa har hørt til dem, der gik i Lære hos Kierkegaard („den mægtige“, som han havde kaldt ham i et Brev til Zahle).

Ogsaa to af Præsterne var dybt berørte af den store Urovækker. Fibiger maatte opleve lidt af hvert. Han fik et Brev, der sluttede: „Luk De Deres Kirkedør og skriv udenpaa: Her vrøvles ikke mere af J. Fibiger, Sjælemyrder." En Gang havde „Dannevirke“ skrevet, at Præsterne hverken kunde eller vilde røgte den Tjeneste, Herren havde sat dem til. Dagen efter prædikede Fibiger i Gammel Haderslev Kirke, og da han saa Koch sidde der, sagde han, at et Dagblad ikke burde belære Folket om, hvad det ingen Forstand havde paa. Om Eftermiddagen gik han op til Koch og fandt ham meget oprørt. Men da Fibiger sagde: „For Resten har jeg altid været af dem, der med Bæven sidder ved Kierkegaards Fod, " var Koch lige ved at omfavne ham. Resultatet blev, at Fibiger fik Lov til i „Dannevirke“ at skrive religiøse Betragtninger, hvori han søgte at lægge Kierkegaards svære Dommedagsslag til Rette, saaledes at kristne Mennesker 
kunde faa besindige Tanker om, hvad der sker med os, og ikke fortvivlede Tanker om sig selv og onde om deres Medmennesker. Saa forkyndte han da om den snævre Port, om Alvoren i Synd og Frelse.

Blandt andet i Samtaler under Roture paa Haderslev Dam drøftede Fibiger Evighedsspørgsmaalet med Kofoed-Hansen, som var en af dem, der forstod Kierkegaard allerbedst. Allerede før Haderslevtiden havde han i Afhandlinger beskæftiget sig med den store ensomme; nu efter hans Død skrev han et Par Skrifter, hvori han skarpt tog hans Parti mod Martensen. Men kunde han da vedblive at være Præst? 1857 indgav han faktisk sin Afskedbegæring, men fik en længere Ferie og blev saa i Embedet. Der var én Ting, som dog tilsidst afgørende skilte ham fra Kierkegaard: dennes absolute Individualisme. Kofoed-Hansen kunde ikke undvære et Samfundsliv, en stor religiøs Organisme, og heri har dog ogsaa Præsten sin Plads som „det Helliges Bestyrer". Mod Slutningen af sit Liv blev han endda drevet til at træde over til den katholske Kirke.

I 859 blev Fibiger forflyttet til København. Hans I86o udnævnte Efterfølger baade som Lærer ved Latinskolen og som Præst ved Hospitalskirken blev Jensinius Johansen (1827-1902); han havde som frivillig Underofficer deltaget i Krigen og nogle Aar været Præst paa Christianshavn. Af Vækst en lille Mand kunde han i Begavelse heller ikke maale sig med Helweg, Kofoed-Hansen og Fibiger. Men han var en alvorlig Præst og en modig Mand.

Til at begynde med fandt han Forholdene rolige; ikke faa hjemmetyske Familier sluttede sig til hans Menighed, maaske tildels, fordi der havde været Uenighed om hans Udnævnelse, og det forlød, at han skulde være bleven ansat imod den danske Embedsstands Ønske. Men med Krigens Udbrud skiltes danske og tyske fra hinanden i et $\mathrm{Nu}$. En Del, som maaske i Stilhed havde været tysksindede, optraadte pludselig bittert danskfjendtligt.

Latinskolen blev lukket og de fleste Lærere udvist, dog ikke Johansen, der vedblev at være Hospitalspræst.

23. April blev Helweg anklaget af en Tilhørerinde for sin Bøn for Fædrelandet. Han blev arresteret af Militæret og kun løsladt, da Provst Kofoed-Hansen gik ind paa at suspendere ham. Men II. Maj blev han afsat; s. D. afsattes Kofoed-Hansen som Provst, I. Juni tillige som Sognepræst ${ }^{1}$.

1 De følgende Meddelelser om de preussisk-østerrigske Anordninger samt om Afskedigelser og Udnævnelser fra Verordnungsblatt für das Herzogtum Schleswig (ogsaa paa Dansk); Meddelelser om Begivenhederne i Slesvig siden den preussisk-østerrigske Invasion, I. November I 864 og Holger Rørdams Fortegnelse over de afsatte Præster i Evangelisk Ugeskrift, Bd. XII, I8. November 1864 . 
I denne Tid var sket en Begivenhed, der er som Symbol paa, at en for Danskheden lykkelig Tid lagdes i Graven: Laurids Skaus Begravelse I8. Maj paa Gammel Haderslev Kirkegaard, medens østerrigske Tropper paraderede paa Gaden udenfor. Kofoed-Hansen holdt Talen over ham som „et Skud af Folkets Livsrod, deres inderste; et herligt Skud; her kan gaa lange Tider, der kan gaa Aarhundreder, før der udsendes et lignende". Men han skjulte ikke, at ogsaa Skau havde erfaret, at Folkegunsten er som en Moder, der forkæler sit Barn. Helweg havde ogsaa udarbejdet en Tale, hvor han fortalte, hvordan han forgæves havde forsøgt aandeligt at hjælpe den afdøde; det offentlige Liv med dets store Farer stillede sig hindrende i Vejen; men da Skau havde vundet sig et Navn, som skal leve med Folket, var det ham tilsidst om at gøre at frelse Livet. Autoriteterne vilde imidlertid ikke tillade andre end Kofoed-Hansen at tale ${ }^{1}$.

$\mathrm{Nu}$ var Tiden kommet for de Mænd, som havde maattet rømme Landet I850. ReнноғF blev 21. April beskikket til at reorganisere Hertugdømmets Kirke- og Skolevæsen. Da han afslog at blive Generalsuperintendent, blev den i Rinkenæs fødte Bertel Godt fra I. August Kirkens øverste Tilsynsmand. 2. Maj havde Rehhoff udsendt et Cirkulære om Afskaffelse af en Række danske Lærebøger i Skolerne. Blandt Bøger, som kan bruges, nævner han: „De 52 Historier fra Forlaget i Calw, som er oversat paa Dansk af Pastor Prahl." Hermed skulde fjernes en Nybearbejdelse af denne Bog, som den danske Præst Andreas Leth i Aabenraa i Mellemtiden havde foretaget, hvori der var indført sproglige Endringer og tilføjet en Udsigt over Kirkehistorien i dansk Aand ${ }^{2}$. Det skyldes sikkert ogsaa Rehhoff, at Prahl blev Kofoed-Hansens Efterfølger som Præst i Gammel Haderslev og Provst. Men hvem skulde være Førstepræst ved Frue Kirke, hvor der nu atter var indført tysk Sprog ved Højmessen?

Strodtmann havde netop udarbejdet en Fremstilling af sin Afskedigelse, med ubeherskede Angreb paa Boesen og Helweg, da Frederik VII døde og Krigen udbrød. Han udsendte nu Skildringen (i Satura) Februar I864, og dedicerede den $\mathrm{i}$ „underdanigst Ærbødighed“ til „Hans Højhed Hertug Frederik VIII af Slesvig-Holsten, der er lige saa kaldet til som besluttet paa atter at bringe det længe trælbundne Broderland Frihed, Ret og Retfærdighed“. Han levede jo uden Embede i Wandsbeck og følte sig aabenbart berettiget til at faa sin gamle

${ }^{1}$ Kofoed-Hansens Tale er trykt. Helweg har offentliggjort sin i Budstikken I864. Jfr. ogsaa P. Skau: Minder fra mit Liv og min Tid. I9og, S. ıog. ${ }^{2}$ Om denne Udgave G. Himmelstrup i Sønderjydske Aarbøger 1924, S. 59; 69. 1895 udgav Pastor H. S. Prahl en forøget og forbedret Udgave af sin Faders Bog, ogsaa med bedre Illustrationer. 
Stilling igen. I to Breve til Prahl fra I 7 de og 25 de August ${ }^{1}$ udtaler han, at der rigtignok gaar Rygter om, at Embedet faktisk er besat, uden at man dog ved, hvem den lykkelige er; at Rehhoff ikke var for ham, turde han vel antage; men hans Regimente var jo nu til Ende, og derfor opgiver han ikke alt Haab.

Det var imidlertid rigtigt nok, at en anden var udset. Hvorfor vilde man ikke have Strodtmann, som dog unægtelig nu var nær til det? Maaske af den Grund, han selv anfører: at han var 67 Aar; dog mente han at kunne forvalte sit gamle Embede nogle Aar uden Skade for Menigheden. Maaske var man bange for hans Fanatisme i Politik; Prahl tog meget roligere paa Tingene; hans begejstrede Tilslutning til Augustenborgeren var maaske heller ikke Preusserne behagelig; Prahl skal have hørt til den preussiske Side. Endelig kan der have været rent personlige Omstændigheder, som maaske ogsaa kan forklare, at han ikke havde faaet Embede i Tyskland.

Den, man havde udset, var Múller, før i Hammelev, nu Provst i Doberan i Mecklenburg. Et Brev fra ham til en Svoger i Haderslev, Raadmand ("Senator") Holm, fra 25. Juli viser, at der gennem Svogeren er kommen en underhaands Opfordring til at søge Embedet. Han drages meget mod den Menighed, i hvilken han er bleven døbt, konfirmeret og viet. Det tiltaler ham ogsaa, at der er tysk Kirke- og Skolesprog; det er nu blevet ham det naturligste og særlig kært, omend han jo fra før har været vant til Dansk. Men han er endnu ikke klar over, om det er Guds Vilje. Han har især to Betænkeligheder. Den ene er Hensynet til Strodtmann; hvis han har et retligt Krav, maa Müller jo ikke gaa ham i Vejen. Den anden Betænkelighed er Hensynet dels til hans nuværende Landsherre, dels til de politiske Forhold. „Du vil indrømme, min kære Svoger, at jeg kun kan ønske at blive i det gamle Fædreland, især i Nordslesvig, dersom det $i k k e$ atter bliver dansk. Ganske vist tror jeg, at Faren i denne Retning er ovre; men vide det kan man dog ikke; thi definitivt er vort dyrebare Fædrelands Skæbne jo endnu ikke afgjort." Han vil da søge Audiens hos Storhertugen af Mecklenburg-Schwerin, sikre sig hans Tilslutning til at gaa til Haderslev og udbede sig den Gunst, at han atter kunde faa Ansættelse i Mecklenburg, dersom de politiske Begivenheders Gang mod Forventning skulde gøre hans Forbliven i det gamle Fædreland umulig. Han havde ogsaa gerne villet tale med Rehhoff, men erfarer, at han I. August vendte tilbage til Hamburg.

Dette Brev har Svogeren overgivet Prahl, og denne spørger i et Brev af 5 . August, om han maa gøre Skridt til at "das Hauptpastorat zu Sct. Marien“ bliver over-

1 Disse Breve og de andre i det felgende benyttede Skrivelse findes i Haderslev Provstearkiv i Arkivdepotet i Aabenraa. 
draget Müller. Han mener, at omend meget er ødelagt i Menigheden, er der dog endnu saa mange gode Elementer, at Müller kan faa et velsignet Arbejde i den By, hvor hans Vugge stod. Spørgsmaalet om Strodtmann berører han ikke, men udtaler sin Billigelse af, at Müller vil tale med sin Landsherre - han har selv gjort det tilsvarende - og han tilføjer: „Om den Mulighed, at Danskerne igen skulde komme til Magten i Slesvig, kan der vel ikke for Alvor være Tale.“ Af et Brev fra Müller til Prahl fra 25. August synes at fremgaa, at han i en mundtlig Samtale har svaret afvisende. Men nu er han kommet til den Overbevisning, at det umulig kunde billiges, dersom Strodtmann vilde gøre et ubetinget Krav gældende. Og saa sender han da sin Ansøgning. 12. September blev han udnævnt.

Provst Prahl, som nu var sat paa den første Plads i Kirken i Haderslev, havde bevist sit tyske Sindelag ved at lide derfor. Men han vilde vare Kirkens Tjener, og han kendte Forholdene godt nok til at vide, at det var umuligt at negligere det danske Element. De Skrivelser, Prahl sendte Provstiets Præster, var oftest affattede paa Dansk. Ja selv fra Generalsuperintendent Godt kan man finde Skrivelser paa Dansk.

Johansen fortsatte som Hospitalspræst indtil I87o. Han giver i sine Erindringer meget levende Billeder af Forholdene. Det er mærkeligt, saa meget man taalte af ham. Da Generalsuperintendent Godt i en Rundskrivelse, som skulde oplæses i alle Kirker paa I. Søndag i Advent I864, havde anordnet en Takkefest, fordi „Preussens og Østerrigs sejrrige Vaaben havde banet Vejen til en Fred, der maa fylde os med levende Glæde“, stemplede Johansen i en Samtale med Prahl Rundskrivelsen som forargelig. Provsten indrømmede, at den var utilbørlig; men han kunde ikke fritage Johansen for Oplæsningen. Johansen svarede, at hvis han skulde oplæse den, maatte han først nedlægge en Protest imod den. Og det gjorde han - med det Resultat, at hele Menigheden forlod Kirken før Oplæsningen. Der skete ham ikke noget i den Anledning.

Da Johansen ønskede at oprette en dansk Realskole, støttede Prahl ham kraftigt i dette Forehavende overfor Myndighederne. Og da Skolekollegiet i Vor Frue Sogn bestandig gjorde Vanskeligheder, blev Skolen aabnet i Gammel Haderslev Sogn, hvor Prahl stod for Styret. Ved Prahls Begravelse I869 bragte Johansen ogsaa en Tak til ham paa de danske Børns og Forældres Vegne. Johansen maatte overgive Skolen til en anden, men den bestod til i 88r. En Lejlighed, hvor Prahl gjorde den spirende, væsentlig danske Indre Missionsbevægelse en Tjeneste, var det Møde i Vojens 20. August I868, hvor man stiftede „Foreningen af i 868 “ for Lægmandsmission, kristelig Diakoni og Børneforsorg. Man 
frygtede Angreb fra Præsternes Side og havde derfor bedt Provsten som den eneste Præst med til Mødet. I Flensburger Norddeutsche Zeitung for 25de August fandtes en Notits om Mødet, med den Bemærkning: "Sagen synes ikke at være fri for politisk Partifarve, da ifølge de foreliggende Efterretninger kun bekendte Dansksindede har deltaget i Forsamlingen. " Prahl tilsendte da Redaktionen et Brev ${ }^{1}$, hvori han som den, der havde overværet hele Mødet og sluttet det med Bøn, protesterede mod denne ganske uretfærdige Insinuation.

Langt mindre gunstigt bedømte Johansen Pastor Müller, hvem han kalder en fanatisk Slesvigholstener. Det er sikkert, at Müller ikke var saa vidsynet $i$ sproglige Spørgsmaal som Prahl. Müller og det af Civilkommissærerne udnævnte Skolekollegium arbejdede paa at faa Frue Sogns Skoler gjort tyske; det var jo en Doktrin, at den gamle Tilstand i Byerne skulde føres tilbage, skønt den nu var end mere unaturlig end før. Da spurgte Johansen ham, hvordan han, der saa op til Luther som Kirkefader, kunde gaa med til at berøve Børn Modersmaalet ved Religionsundervisningen. Da Müller blev haardt trængt, sagde han tilsidst, at egentlig skulde Undervisningen gives paa Bibelens Grundsprog, Hebraisk og Græsk! Han synes at have været ikke lidt højkirkelig; i et Par Artikler om Kirkeforfatningsspørgsmaalet i Schleswig-holsteinisches Kirchen- und Schulblatt ( 1867 Nr. 33 og 4I) betoner han stærkt, at hvis man skal have en Forfatning, maa den være konservativ med stærk Hensyntagen til Embedet.

Naar Müller var saa uvillig overfor Johansens Drengeskole, faar man det Indtryk, at det maaske ogsaa skyldes, at Johansen flere Gange meget kraftig havde sagt ham Besked. Overfor den danske Pigeskole, som Frk. Louise Tauber ledede med saa stor Dygtighed og Takt, var Müller en i Grunden ikke uvenlig Tilsynsmand $^{2}$. Den blev først lukket 1888 .

I 869 døde Provst Prahl. Og Aaret efter maatte Johansen opgive sit Embede. Han havde 1867 aflagt Eden til den preussiske Konge, men han kunde ikke bede den foreskrevne Bøn for de tyske Vaaben i Krigen mod Frankrig. Derfor gik han, ligesom f. Eks. Provst Blædel i Nustrup og Pastor Grove Rasmussen i Fole.

Og hermed ender et Afsnit af Haderslevs Kirkehistorie, hvor Traadene slyngede sig sælsomt sammen. Nu forsvandt de sidste Præster fra Danmark. Men i den følgende Tid skulde det nordslesvigske Lægfolk selv blive bærende paa en Maade, som hidtil var ukendt.

\footnotetext{
1 Koncept i Provstearkivet. Om Foreningen forøvrigt Asylvennen Aug. I928 og Aug. I930. ${ }^{2}$ Herom Henriette Skram i Gads danske Magasin, Aug. 1916, og Sønderjydske Kvinder under Fremmedherredømmet, I, $193^{\circ}$.
} 